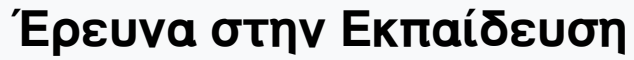

Tóp. 6, Ap. 2 (2017)

Special Issue: Lesson Study - A Scientific Meeting for Exchanging Views and Exploring the Model Across Europe

Special Issue dedicated to the Scientific Symposium with International Participation: Lesson Study: A Scientific Meeting for Exchanging Views and Exploring the Model Across Europe, Alexandroupolis, 7 and 8 March 2017
Construction of a discursive community during a lesson study. An example of geography in a primary French-speaking class

Sandrine Breithaupt, Alain Pache

doi: $10.12681 /$ hjre.14801

\section{Copyright (C) 2017, Sandrine Breithaupt, Alain Pache}

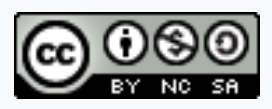

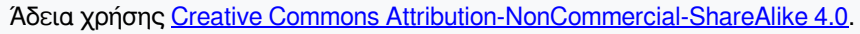

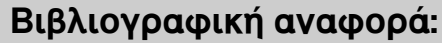

Breithaupt, S., \& Pache, A. (2017). Construction of a discursive community during a lesson study. An example of geography in a primary French-speaking class. 'E https://doi.org/10.12681/hjre.14801 


\title{
Construction of a discursive community during a lesson study. An example of geography in a primary French-speaking class
}

\author{
Sandrine Breithaupt, Professor, Alain Pache, Professor \\ University of Teacher Education, State of Vaud, Lausanne, Switzerland
}

\begin{abstract}
The aim of this article is to analyse language activity during a research lesson in geography with pupils aged 8 to 12, in the French-speaking part of Switzerland. We highlight the role of discursive modes in the construction of a discursive disciplinary community.
\end{abstract}

(C) 2017, Breithaupt S., \& Pache A.

Keywords: lesson study; secondarisation; discursive community

\section{Introduction}

The lesson study group in geography was set up in June 2015 due to a concern we had as trainerresearchers at the university of teacher education in Lausanne, Switzerland. We were seeking to better understand the processes of 'secondarisation' (Bautier \& Goigoux, 2004; Philippot \& Bouissou, 2006) in the teaching of social science in primary schools (aged 8 to 12) and, on the other hand, to implement new teaching methods in geography. We appealed to teachers interested in the subject and subsequently launched a lesson study that lasted two consecutive years. In this article, we present analyses based on data collected during the first year of work, highlighting links between language practices and pupils' learning.

\section{Conceptual framework}

Our work brings together two theoretical perspectives: the first, known as historical-cultural, sociohistorical or vygostkian (named after its precursor Vygotski), elaborated in the works of Bodrova and Brunner amongst others in the English-speaking world and Brossard, Schneuwly, and Rochex in the French-speaking world. The second, known as enunciative, was developed by Benveniste, Bakthine and Jacques and more recently by Charaudeau, Maingeneau and Nonnon ${ }^{1}$.

As a follow-up to these works, we explored the concepts of 'secondarisation' (Bautier, 2006, Bautier \& Goigoux, 2004, Philippot \& Bouissous, 2006) and the discursive community (Bernier, 2004; Jaubert, 2007), two concepts that are fundamental to our research.

\footnotetext{
${ }^{1}$ We make no reference to particular articles here, as they are so numerous. An Internet search will produce the necessary information to readers who are motivated to read further.
} 
Hellenic Journal of Research in Education, Special Issue dedicated to the Scientific Symposium with International Participation: Lesson Study: A Scientific Meeting for Exchanging Views and Exploring the Model Across Europe, Alexandroupolis, 7 and 8 March 2017

\section{Secondarisation}

The term 'secondarisation' refers to a process that is characterized by a shift in pupils' approach to understanding the world and knowledge from a practical point of view to one that is symbolic (Philippot \& Bouissou, 2006).

Bautier (2006) points out that some learning difficulties are linked to the process of secondarisation. Indeed, some pupils face difficulties identifying the cognitive issues and knowledge objects presented in school tasks and activities. For example, when performing tasks such as colouring puzzles according to numbers, some pupils usually say they are learning to colour, while others say they are learning numbers. Thus, in a given task, pupils do not all have the same understanding of the learning issues aimed at by the teaching. Some pupils invest in school tasks with first-order thinking centred on 'doing' that is spontaneous and anchored in specific experience and particular situations; action takes precedence over the activity and immediate success. Other pupils employ second-order thinking that is reflective and generic, where specific situations are gradually de-contextualized and knowledge is generalized, and situations are understood in their different spontaneous and scientific dimensions. The logic of these pupils is that of "learning", in which a reconfigured relationship to the real world takes precedence.

The term "secondarisation" has its origins in the work of Bakhtin (1984) who distinguishes different genres in literary production. Transferred to the field of educational sciences, the notion allows us to consider language practices as indicators of secondarisation. When a pupil expresses himself, he makes use of diverse and heterogeneous language genres. In doing so, he indicates the genre in which he is situated and thus the coherence of his discourse can be related to the positioning expected of him in his sphere of activity (Bautier \& Goigoux, 2004).

\section{Discursive community}

During classroom exchanges, pupils as well as the teacher express themselves according to their own points of view. The class thus appears, as a socio-discursive space in which knowledge and other objects of discourse are at first heterogeneous; each speaker expressing different 'voices', different points of view. Progressively, through confrontation, negotiation and justification and differing discourses move closer together. An order emerges that "reorganises discourses according to certain properties, makes adjustments, reformulations, extracting propositions from their initial, singular context." The result is a discursive community "organized around certain practices, values and 'scholarly' knowledge constructed by and subjected to the criticism of its members" (Jaubert, 2007: 113). This is the case with the acquisition of school knowledge. "Each participant can thus formulate a statement by explaining it, questioning it, conceptualizing it, etc., distancing himself from it or adhering to it" (Breithaupt, 2017, p. 10). Authors speak of a discursive community of school subjectmatters (Bernié, 2002, Jaubert, Rebière \& Bernié, 2003, Jaubert, Rebière, 2012).

\section{Research questions}

Beyond the work of Philippot (2008, 2009), Le Marec (2007) and Pache (2012), there are relatively few works about secondarisation in teaching humanities and social science, particularly in geography. In the context of primary education, Philippot's work shows that teachers themselves have not developed a second-order relationship to the subjects taught, despite their training. Consequently, they restrict themselves to teaching tasks requiring little reflective capacity. Le Marec highlights the omnipresence of the teachers' discourse and the relative absence of it in pupils. In her thesis, Pache shows the predominance of certain words related to the everyday life, to the detriment of concepts derived from university-based geography.

We therefore raise two questions:

1) What is the nature of language use in a geography lesson? 
Hellenic Journal of Research in Education, Special Issue dedicated to the Scientific Symposium with International Participation: Lesson Study: A Scientific Meeting for Exchanging Views and Exploring the Model Across Europe, Alexandroupolis, 7 and 8 March 2017

2) In relation to the first question, what are the indicators of a secondarisation process within the framework of teaching geography?

\section{Methodology}

Our methodology is a part of a training-research process called "lesson study". Inspired by the Japanese tradition Jugyou kenkyuu, 'lesson study' is the English translation of a secular Japanese practice that has only relatively recently been adopted in the francophone world.

"What characterizes lesson studies (LS) is that, first they are carefully planned on the basis of a teaching or learning problem by a group of teachers, sometimes in association with researchers or university professors. They are focused on the teaching and learning process of pupils (Lewis \& Tsuchida, 1997, Takahashi \& McDougal, 2015). Second, they take place under the observation of peers or school partners. Finally, they are recorded and discussed, sometimes with people from outside the set-up, qualified as experts (what Takahashi, 2014, calls knowledgeable others). The impact of the approach can be measured in terms of improvements in teaching practices, dissemination of new content, the linking of prescriptions and practices (Lewis \& Tsuchida, 1998), and bringing together the worlds of practitioners and researchers (Clerc-Georgy \& Clivaz, 2016)" (Breithaupt, 2017, pp. 7-8).

The LS system implemented in the current research took place from September 2015 to June 2016. Four teachers and two teacher-researchers were involved and the LS took the form of three cycles. The first required four preparatory meetings each of which demanded about two hours before the first research lesson which was followed by a small break for debriefing. The second cycle, comprising both of an analysis of the first research lesson and a reorientation for a second research lesson, required two encounters. The same was true for the third cycle, which ended with an evaluation of the overall approach. Figure 1 schematizes the three cycles.

\begin{tabular}{|l|l|l|l|l|l|l|l|}
\hline Prep 1 & Prep 2 & Prep 3 & Prep 4 & $\begin{array}{l}\text { Research } \\
\text { Lesson 1 } \\
\text { Debriefing }\end{array}$ & $\begin{array}{l}\text { Analysis } \\
\text { Prep 1 }\end{array}$ & $\begin{array}{l}\text { Analysis } \\
\text { Prep 2 }\end{array}$ & $\begin{array}{l}\text { Research } \\
\text { Lesson 2 } \\
\text { Debriefing }\end{array}$ \\
\hline $\begin{array}{l}\text { Analysis } \\
\text { Prep 1 }\end{array}$ & $\begin{array}{l}\text { Analysis } \\
\text { Prep 2 }\end{array}$ & $\begin{array}{l}\text { Research } \\
\text { Lesson 3 } \\
\text { Debriefing }\end{array}$ & Assesment & & & & \\
\hline
\end{tabular}

In this article, we intend to focus on data from the first two research lessons that we have filmed and the transcription of it, which constitutes our corpus.

The knowledge that "learning is the result of overcoming contradictions and tensions generated in the classroom, which, in terms of language, presupposes the construction of a relevant enunciative position, the ability to situate oneself by one's discourse, by the genre adopted, in the sphere of a discipline-based exchange, leads us to clearly assume a certain number of values and presuppositions and simultaneously renounce others" (Jaubert, 2007, p. 99). We thus briefly describe the lesson as planned, we then analyse some extracts verbatim. We concentrate on a relatively emblematic activity in humanities and social science, namely the creation of a list of non-exhaustive elements for classification. The analysis is that of speech and the content of interactions (Bardin, 1997).

We are particularly interested in the knowledge expressed by pupils and the teacher during the production of a list, seeking to identify possible points of view expressed (from daily life or 
spontaneous experience or, more scientifically, as the observations of a geographer). Then, we try to identify the mode or modes of construction of the discursive community during the interactions. We rely on the work of Jacques (1991), reprinted by Nonnon (1997) and use the following categories:

- the dialogue mode enables a dialogue between different enunciative voices and, as such, is capable of inducing learning. Indeed, this mode allows for the highlighting of possible opposing or complementary positions, by seeking to agree on what can be considered to be true. In a way, the dialogue mode opens up a dialectic (in reference to Aristotle and as opposed to "the eristic dialogue, where it is first necessary to prevail over the adversary, implying an indifference to truth", Perelman, 1989, quoted by Nonnon, 1997, 14).

- the conversation mode regroups exchanges that express a feeling of belonging to a community, via relational aspects or by the way speakers address each other.

- the negotiation mode concerns exchanges aimed at reaching a compromise or a consensus on various points of view expressed without a dialectic being established. Here, it is a question of negotiating points of view, without examining the proposals, and in the process doing away with the tensions that potentially generate learning.

\section{Results and analysis}

The lesson study implemented here pursues the following objectives (excerpted from the official curriculum in the French-speaking part of Switzerland):

- Identify different parts of a place and the relationships between them, their functions and uses (habitat, leisure, supply, exchanges, reception, passage, activity, transformation, ...).

- Locate and identify the means used (human-related facilities) to:

- distinguish areas and mark their boundaries,

- link different places, areas, territories,

- embellish, secure, attract,

- avoid/reduce problems caused to people and the environment.

The central concept at stake in this objective is the organization of space and the lesson has been organized into five phases:

1) Collectively list facilities for animals identified along the way to school.

2) Plot the home-school itinerary on a map.

3) Symbolise the facilities identified.

4) Compare maps to identify areas of development.

5) Write a text explaining what has been learnt.

To improve understanding of linguistic practices and the process of secondarisation, the lessons were transcribed verbatim. Our analysis here focuses on the development of the list of facilities identified on the home-school route during the first and second research lesson. For each lesson, we present some salient and emblematic elements, allowing us to highlight links between language practice and learning.

\section{First research lesson}

The first research lesson lasted an hour and a half. During the first phase of the lesson, the following elements appeared chronologically: 
1. Equestrian shop

2. Dog grooming salon

3. Dog poop disposal bags

4. Forbidden signs

5. Bird shelters

6. Signs against dog poop

7. Signs for dogs

8. Hooks, poles

9. Hen house

10. Enclosure for cows

11. Vet

12. Manege

13. Pet shop

14. Space for sheep

15. Indoor space

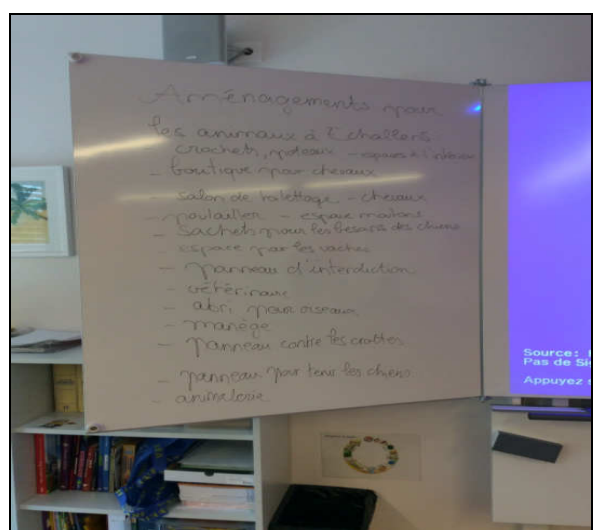

Analysing the interactions that lead to the establishment of this list, we first notice that the pupils do not state what they actually found on their way to school. As soon as the first child proposed the "horse shop", the second proposes the "dog grooming salon". The list is constituted by association of ideas, not by the restitution of observations. This way of proceeding is not structured and will result in the feeling of juxtaposed tasks, with no explicit link between them. The activity of geographer embodied in the objectives is, as a result, barely accessible.

Secondly, it should be noted that during the process, some proposals are retained and placed on the board, while others are rejected. The two excerpts below illustrate this phenomenon.

Louis's proposition which is not retained:

\begin{tabular}{|c|c|}
\hline Teacher & ((note on the chart) $)$ mmm hooks hooks poles ok. Louis, you raised your hand? \\
\hline Louis & Home. \\
\hline Teacher & Home? \\
\hline Louis & yeah for my cat. \\
\hline Teacher & yes but then it's not expressly for your cat? \\
\hline Louis & yes but downstairs there is a place with cushions. \\
\hline Pupils & $\underline{\text { Yes me too }}$ \\
\hline Teacher & $\begin{array}{l}\text { OK what is the difference between what's inside your house and what's on the street } \\
\text { outside? What is the difference between just the place where you gonna put small pillows } \\
\text { just and hooks and poop bags? }\end{array}$ \\
\hline Louis & it's for all dogs. \\
\hline Teacher & $\begin{array}{l}\text { this is really for your pets and it is you who put them there. so maybe we will -that would } \\
\text { make a little too much to list if one were to take the elements of each. Guillaume? }\end{array}$ \\
\hline
\end{tabular}


Guillaume's proposition that was retained:

\begin{tabular}{|l|l|}
\hline Gui. & a chicken house. \\
\hline Teacher & a chicken house ? \\
\hline Gui. & yes there there are doves. \\
\hline Teacher & yes but are you speaking again about your house? \\
\hline Gui. & my chicken house and the one that belongs to my neighbours. my neighbours' barn. \\
\hline Teacher & $\begin{array}{l}\text { OK, if you - well I want you to stay focused on the things humans have built but that are } \\
\text { most likely outside your home. }\end{array}$ \\
\hline Gui. & Yes they built it and it is outside their home. \\
\hline Teacher & but it is not yours? \\
\hline Gui. & No. \\
\hline Teacher & Ok. What's the name again? \\
\hline Gui. & a chicken house. \\
\hline Teacher & a chicken house - and then? Eliott? \\
\hline
\end{tabular}

These two extracts provide some insight into language practices involved in negotiation. Indeed, for pupils it's a question of stating propositions that will be retained or rejected depending on their arguments and what underpins them. The cat house is refused, without evoking the nuance between public and private facilities. The henhouse is accepted because Guillaume shows that it meets the teacher's requirements: it is built by humans, outside their home and they do not own it. The teacher uses first order language. Second-order vocabulary such as "layout", "public or private space" is absent. Instead there is mention of "things" or of what is built in or out of pupils' dwellings. The interaction continues until the whiteboard is covered with proposals. The activity is then considered complete.

This has at least two consequences. The first is that the pupils act, moving forward tentatively, trying to guess the teacher's expectations, arguing in favour of their proposal so that it is written up on the board. The purpose of the task is thus diverted from its primary aim of constituting a list of facilities observed on the way to school. What's more, the end of this phase of the lesson is dictated by the lack of space on the board. The second is that the necessary dialectic to be established by the study of the different propositions cannot be achieved. Indeed, part of the classification, that the pupils are unaware of, springs from the acceptance or rejection of the teacher's proposals. Understanding the term 'planning' in this context cannot be achieved and the rest of the lesson, which consists in identifying the different areas planned for animals, is jeopardised.

The lesson study makes it possible to highlight these phenomena and the group decides to retain all the pupils' proposals during the second research lesson. In addition, having become aware of the difficulties of conceptualizing the word 'planning', it is decided that, following the list, pupils will categorize the facilities in order to be able to identify the characteristics of each (e.g. intentionally manufactured by 'man for animals'). 


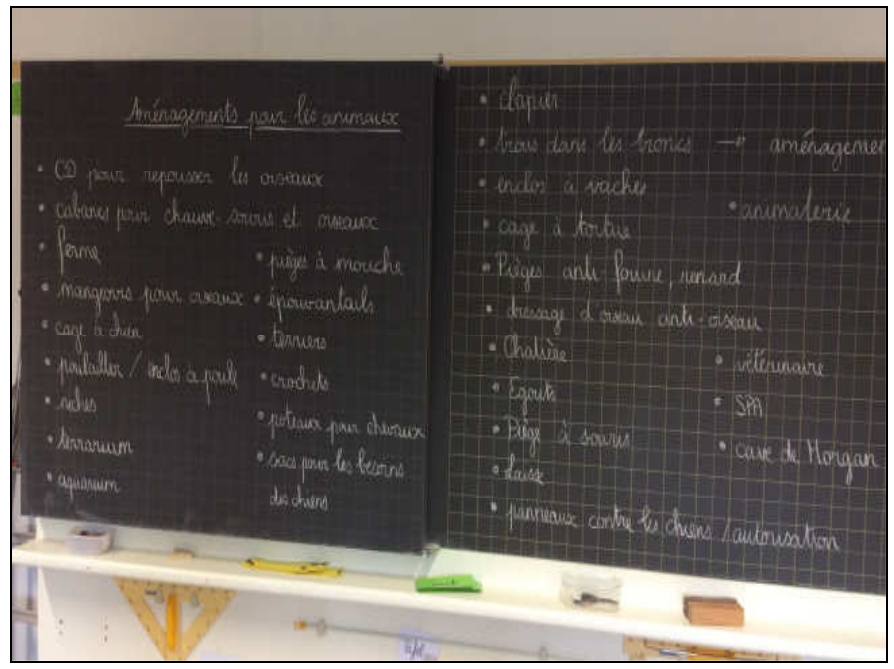

\section{Second research lesson}

This second lesson lasts 45 minutes. By observing the image provided here, the reader will notice that pupils' proposals are more numerous than during the first lesson. There are 34 in all. In fact, practically no proposal is rejected by the teacher. However, analysing the process, it is apparent that, here too, the class loses sight of its initial task (listing facilities on the path to school) and ideas are emitted by association. Some proposals are sufficiently strange in the eyes of the teacher, who asks pupils to limit themselves to the area around the school, yet she accepts most propositions without prior judgment.

This constraint to accept all propositions produces changes in the interaction. In the following example, Malo proposes "holes in trees" (which does not quite fit the definition of planned developments). The teacher retains the proposal, which makes Lou react. The teacher lets some uncertainty prevail by indicating that the characteristic of 'size' will be raised later.

\begin{tabular}{|c|c|}
\hline Malo & Holes in the trees for anim... I mean for birds or the ... \\
\hline Teacher & $\begin{array}{l}\text { Holes in trees ((TURNS TO WRITE BUT CHANGES HER MIND)) the } \\
\text { holes um when you see a hole um you mean there in the trunk? ((POINTS OUT THE } \\
\text { WINDOW)) }\end{array}$ \\
\hline Malo & Yes \\
\hline Teacher & OK ((WRITES HOLES IN TRUNKS ON BLACK BOARD 12 SEC)) what else, Lou \\
\hline Lou & $\begin{array}{l}\text { But it fact it's it's um from holes um in the trunk but if the hole is too small it is too } \\
\text { natural but if we were to make it we would make it a little bigger }[\ldots]\end{array}$ \\
\hline Teacher & But why would you not agree that we chose holes in trees then \\
\hline Lou & $\begin{array}{l}\text { It's not that I don't agree but it should be big enough for us to remark [...] we can remark } \\
\text { it. That depends on the size }\end{array}$ \\
\hline Teacher & $\begin{array}{l}\text { So is it a natural development or not depending on its size? We will see, hey? What we } \\
\text { say then. What else }\end{array}$ \\
\hline
\end{tabular}


Hellenic Journal of Research in Education, Special Issue dedicated to the Scientific Symposium with International Participation: Lesson Study: A Scientific Meeting for Exchanging Views and Exploring the Model Across Europe, Alexandroupolis, 7 and 8 March 2017

A short while later, Malo suggests "the basement", a similar suggestion to that mentioned in the first research lesson. The reaction here is also different:

\begin{tabular}{|c|c|}
\hline Malo & Um, well, the basement, because my cat is always going in there $[\ldots]$ \\
\hline Jane & $\begin{array}{l}\text { The basement, really, I don't agree with Malo because I don't know if they made it for } \\
\text { him, it's the cat- }\end{array}$ \\
\hline Malo & Yes because we put little things there for him and then we put a bowl of food \\
\hline Jane & $\begin{array}{l}\text { In that case you could almost say that you organised (STRESSING THE POINT) a little } \\
\text { corner for him in the basement well I say you didn't convert your basement rather it is } \\
\text { the cat that wanted to go in there it's not you that built your basement }\end{array}$ \\
\hline Malo & Yes it was my grandfather that built the basement ((SEVERAL PUPILS LAUGH)) $[\ldots]$ \\
\hline Teacher & $\begin{array}{l}\text { Raise your hand those who want to keep the basement frankly I accept I don't care one } \\
\text { way or the other ((COUNTS RAISED HANDS)) oh but we are going to write we are } \\
\text { going to write Malo's basement }\end{array}$ \\
\hline
\end{tabular}

This extract highlights a discussion of the definition of 'planned developments'. Jane and Malo disagree. The teacher takes no position but lets the pupils debate and eventually has them vote for the presence of the term on the board.

An analysis of the language activity during this lesson reveals first-order and sometimes secondorder language, allowing an emergent conceptualization of the notion of planned development. The discursive modes vary according to pupils' propositions, moving from conversation to the beginnings of dialectic, while sometimes modes seem to be taking on a negotiation mode. We can see the emergence of a dialectic through the different positions of the pupils confronted with the proposals made.

What determines the end of this first phase of the lesson is actually the end of the lesson itself. Indeed, while a phase of categorization of the elements noted on the board was being planned, the time of the lesson had already elapsed ${ }^{2}$.

\section{Conclusion}

The analysis of language practices during the construction of a list or inventory in geography allows us to highlight the role of discursive modes in the construction of a discursive disciplinary community. More specifically, we show that the dialogue mode provokes interactions enabling the creation of a dialectic capable of allowing the construction of disciplinary knowledge. This is probably an indicator of the secondarisation process.

On the other hand, a second indicator could be linked to the acceptance of the heterogeneity of pupils' responses. Indeed, each answer highlights the order in which the pupils are speaking. Taking into account the different positions expressed, it is possible to enable pupils to go beyond them, transforming first-order conceptions into second-order knowledge.

Finally, the lesson study, conceived as a research device, also seems to have effects on teachers and researchers who are called upon to 'secondarise' teaching practices. Indeed, the different phases

\footnotetext{
${ }^{2}$ This led the LS group to change its focus on categorization during the third and final research lesson. However, the analysis of the latter is not the subject of this article. To sum up briefly, the results confirm the hypothesis that there are links between language practices and pupils' learning.
} 
Hellenic Journal of Research in Education, Special Issue dedicated to the Scientific Symposium with International Participation: Lesson Study: A Scientific Meeting for Exchanging Views and Exploring the Model Across Europe, Alexandroupolis, 7 and 8 March 2017

of collective preparation and analysis lead to a particular point of view on the learning process and the teaching-learning process itself. In other words, the lesson study focuses on practitioners' and researchers' attention on the general characteristics of teaching and learning and no longer only on the characteristics of a particular teacher in a particular context. As such, the lesson study is a very promising professional development tool.

\section{Bibliography}

Bakhtine, M. (1984). Esthétique de la création verbale. Paris, France: Gallimard.

Bardin, L. (1997). L'analyse de contenu. Paris, France: PUF.

Bautier, E. (2006). Le rôle des pratiques des maîtres dans les difficultés scolaires des élèves. Une analyse de pratiques intégrant la dimension des difficultés socialement différenciées. Recherche et Formation, 51, 105-118.

Bautier, E. \& Goigoux, R. (2004). Difficultés d'apprentissage, processus de secondarisation et pratiques enseignantes : une hypothèse relationnelle. Revue Française de Pédagogie.

Bautier, E. \& Rayou, P. (2009). Les inégalités d'apprentissage. Programmes, pratiques et malentendus scolaires. Paris, France : PUF.

Bernié J.-P. (2002). L'approche des pratiques langagières scolaires à travers la notion de « communauté discursive » : un apport à la didactique comparée ? In: Revue française de pédagogie, 141, 77-88.

Breithaupt, S. (2017). Savoirs professionnels et communauté discursive en formation continue des enseignants. Le cas d'un dispositif 'lesson study'. Canevas de thèse en sciences de l'éducation, Université de Genève.

Jacques, F. (1991). Argumentation et stratégies discursives. In A. Lempereur (Ed.), L'argumentation (pp. 153-171). Liège, Mardaga: Colloque de Cerisy.

Jaubert, M. \& Rebière, M. (2012). Communauté discursives disciplinaires scolaires et construction de savoirs: l'hypothèse énonciative. Forumlecture.ch, 3. Consulté le 23 mars 2016, dans http://forumlecture.ch/redaktionsbeitrag_2012_3.cfm

Jaubert, M., Rebière, M. \& Bernié, J.-P. (2003). L'hypothèse "communauté discursive": d'où vientelle? où va-t-elle? Les cahiers THEODILE, 4, 51-80.

Pache, A. (2012). Pensée sociale et pratiques langagières de futurs enseignants de l'école primaire vaudoise: l'alimentation vue à travers le prisme de la géographie scolaire. Thèse de doctorat: Université de Genève, $n^{\circ}$ FPSE 515.

Philippot, T. (2008). La professionnalié des enseignants de l'école primaire: les savoirs et les pratiques. Thèse de doctorat en sciences de l'éducation, Université de Reims.

Philippot, T. (2009). Des enseignants de l'école primaire et l'enseignement des matières scolaires: réflexions sur la professionnalité enseignante. Qu'est-ce qu'une formation professionnelle universitaire des enseignants ?, 2, 7-16. Consulté dans http://www.lille.iufm.fr/IMG/pdf/7-16 tome2.pdf

Philippot, P. \& Bouissou, C. (2006). Analyse d'une séance de géographie à l'école élémentaire : regards didactique et socio-didactique. Colloque international des Journées d'Études Didactique de l'Histoire et de la Géographie, IUFM Champagne-Ardenne. Actes sur Cd-Rom. 
Hellenic Journal of Research in Education, Special Issue dedicated to the Scientific Symposium with International Participation: Lesson Study: A Scientific Meeting for Exchanging Views and Exploring the Model Across Europe, Alexandroupolis, 7 and 8 March 2017

Le Marec, Y. (2007). Problématisation et processus de secondarisation en classe d'histoire. Texte présenté au Colloque des didactiques de l'histoire, de la géographie et de l'éducation citoyenne, Valenciennes.

Nonnon, E. (1997). Quels outils se donner pour lire la dynamique des interactions et le travail sur les contenus de discours ? Enjeux (39/40), 12-49. 